\title{
Assessment of Ecotoxicity of Incinerated Sewage Sludge Ash (ISSA)
}

\author{
Waldemar Kępys *(1), Małgorzata Śliwka and Małgorzata Pawul
}

Citation: Kępys, W.; Sliwka, M.;

Pawul, M. Assessment of Ecotoxicity of Incinerated Sewage Sludge Ash (ISSA). Minerals 2021, 11, 849.

https://doi.org/10.3390/min11080849

Academic Editor:

Mostafa Benzaazoua

Received: 18 June 2021

Accepted: 2 August 2021

Published: 6 August 2021

Publisher's Note: MDPI stays neutral with regard to jurisdictional claims in published maps and institutional affiliations.

Copyright: (c) 2021 by the authors. Licensee MDPI, Basel, Switzerland. This article is an open access article distributed under the terms and conditions of the Creative Commons Attribution (CC BY) license (https:// creativecommons.org/licenses/by/ $4.0 /)$.
Department of Environmental Engineering, Faculty of Civil Engineering and Resource Management, AGH University of Science and Technology, Al. Mickiewicza 30, 30-059 Kraków, Poland; sliwka@agh.edu.pl (M.Ś.); pawul@agh.edu.pl (M.P.)

* Correspondence: kepys@agh.edu.pl

\begin{abstract}
Combustion in fluidised bed boilers is one of the most commonly used methods of treatment of municipal sewage sludge. Fly ash (FA) and air pollution control (APC) residues are the solid by-products generated by flue gas treatment. There are significant differences in the chemical composition of these wastes. FA is composed of mainly $\mathrm{SiO}_{2}, \mathrm{P}_{2} \mathrm{O}_{5}, \mathrm{CaO}$ and metals such as $\mathrm{Zn}, \mathrm{Ti}, \mathrm{Cu}$, $\mathrm{Cr}, \mathrm{Pb}$ and $\mathrm{Ni}$. APC residues mainly contain $\mathrm{SO}_{3}$ and $\mathrm{Na}_{2} \mathrm{O}$. The leachability tests that were carried out indicate that these wastes display very low leachability of heavy metals (for example leachability of $\mathrm{Pb}$ was equal $0.0004 \mathrm{mg} \cdot \mathrm{dm}^{-3}$ in both wastes, leachability of $\mathrm{Cd}$ was equal $0.0012 \mathrm{mg} \cdot \mathrm{dm}^{-3}$ in FA an $0.00004 \mathrm{mg} \cdot \mathrm{dm}^{-3}$ in APC). On the other hand, very high sulphate concentrations $\left(49,375 \mathrm{mg} \cdot \mathrm{dm}^{-3}\right)$ were found in water extract for the APC residues. In order to determine the toxicity of these wastes for plants, pot experiments with different additions of waste to the soil were carried out (on Lepidium sativum and Sinapis alba). Tests based on seeds germinations (on Lepidium sativum) in water extracts from waste (in different concentrations) were also performed. The results obtained indicate the very high toxicity of APC residues. Complete inhibition of germination and growth of the test plants was found for all concentrations of the tested waste in water extract and for all additions of waste to the soil in pot experiments. Seed germination tests on water extracts from FA did not show any toxicity of this waste. Pot tests with FA showed their toxicity only with a high (30\%) addition in soil.
\end{abstract}

Keywords: incinerated sewage sludge ash; ecotoxicity; waste recovery

\section{Introduction}

The treatment of domestic wastewater results in the generation of sewage sludge, which must be managed in a manner that does not endanger the environment or human health. Hence, this sludge requires stabilisation or other treatment by biological, chemical or thermal means. The most common management options include agriculture, reclamation, thermal processes, and, as a last resort, landfilling [1]. Sludge can also be a source of methane [2] and phosphorus [3].

Thermal processes involve the combustion of sludge in various types of boilers (grate, fluidised bed, rotary), co-combustion with other fuels (coal, municipal waste), pyrolysis or gasification.

Fluidised bed boiler combustion is the most commonly used method [4,5]. The sludge is dewatered and dried before being fed to the boiler to a minimum sludge dry matter content of $36 \%$. This allows for autothermal or near autothermal combustion conditions. The combustion process produces flue gases from which the mineral fraction (fly ash), acid gases $\left(\mathrm{SO}_{\mathrm{x}}, \mathrm{HCl}, \mathrm{HF}, \mathrm{NO}_{\mathrm{x}}\right)$ and heavy metals are removed.

The properties of the wastes resulting from thermal processes depend on the type of sludge burned, the temperature of the process, the type of boiler and the flue gas treatment methods [6,7]. This has significant implications for the opportunities and directions for their subsequent management. 
Incinerated sewage sludge ash (ISSA) is landfilled or may undergo solidification and stabilisation processes. This is to reduce the leachability of contaminants, by changing them from a fine-grained form to larger agglomerates. Most commonly, it involves mixing ashes with cement and water. Another method is granulation or briquetting with binding materials. Ashes or agglomerates can be subjected to high temperatures (vitrification processes). As a result, impurities are built into the structure of the resulting vitreous substance, effectively reducing the impact of atmospheric factors [8]. Ashes processed in this way can be used in construction as artificial aggregates.

Increasingly, ISSAs are used in construction, road building, and as a source of phosphorus $[4,9]$. The primary determinant of utilisation is the chemical composition-the content of main components such as $\mathrm{SiO}_{2}, \mathrm{Al}_{2} \mathrm{O}_{3}, \mathrm{CaO}, \mathrm{Fe}_{2} \mathrm{O}_{3}, \mathrm{Na}_{2} \mathrm{O}, \mathrm{MgO}, \mathrm{P}_{2} \mathrm{O}_{5}, \mathrm{SO}_{3}$ and trace components in the form of heavy metals. The amount of ash used from sewage sludge incineration, which is very often a substitute for natural raw materials, is also not insignificant. Numerous studies on the use of ISSA as a substitute for cement, natural aggregates in mortars and concretes, or as a filler have been published [10,11]. The use of ISSA decreases the strength parameters, as well as the workability of mortars/concrete; however, an appropriate amount of ash can be selected to obtain satisfactory results [12]. Lightweight aggregates (LWAs) are produced from ISSA by sintering pellets. LWAs show low density and thermal conductivity. Thus, they are used for light concrete production, as filler material, and in thermal and acoustic insulation [13]. Furthermore, these wastes can be utilised as a substitute for clay in the manufacture of ceramic materials like bricks and tiles [14]. Another context for their use is related to earthworks. ISSAs can find applications in geotechnical engineering for soil stabilisation. The mixture of ISSA with cement can be used as a soil stabiliser to improve the basic properties of soft subgrade soil, such as compressive strength, swelling behaviour, and California bearing ratio (CBR) [15]. Other studies have indicated the potential for ISSA recovery for backfilling in underground mines $[16,17]$.

In addition, ISSAs can be a source of phosphorus. ISSA phase composition studies [18], indicate that phosphorus occurs as calcium phosphate hydrate- $\mathrm{Ca}_{3}\left(\mathrm{PO}_{4}\right)_{2} \cdot \mathrm{xH}_{2} \mathrm{O}$, hydroxylapatite- $\mathrm{Ca}_{5}\left(\mathrm{PO}_{4}\right)_{3}(\mathrm{OH})$, whitlockite $-\beta-\mathrm{Ca}_{3}\left(\mathrm{PO}_{4}\right)_{2}$ or $\mathrm{Ca}_{7} \mathrm{Mg}_{2} \mathrm{P}_{6} \mathrm{O}_{24}$. Phosphorus is used in the production of fertilisers, feed and in the food industry. The considerable industrial importance and dwindling natural resources have resulted in the EU treating phosphorus as a critical raw material, necessary for economic development [19]. Phosphorus recovery from ISSA is performed using thermo-chemical treatment, electrodialytic or acid leaching processes $[20,21]$.

Due to the presence of phosphorus compounds, research has been conducted on the use of ISSA to remediate lead-contaminated soils. As indicated in [22], mixing ISSA with oxalic acid in appropriate proportions is an effective remediation method for the stabilisation of $\mathrm{Pb}$ contaminated soil. Furthermore, studies performed by Lin et al. [23] indicate that ISSAs have no toxic effects on terrestrial and marine organisms. The occurrence of phosphorus is also one of the reasons for research into the use of ISSA for reclamation or as a fertiliser ingredient [24-27]. Additionally, use in these contexts is connected with determining the influence of ashes on the ground-water environment, vegetation and meeting the environmental requirements in this respect [28]. Therefore, this paper presents the results of ISSA ecotoxicity studies against test plants.

The aim of this study on the physicochemical and ecotoxicological properties of ashes from the combustion of municipal sewage sludge aims to assess the possibility of their natural management as a material for land reclamation (improving soil properties) or fertiliser production. These waste, if satisfactory research results are obtained, could be used as an additive improving the properties of land in degraded areas, not only in an experimental but also in a commercial manner. 


\section{Materials and Methods}

Waste from a fluidised bed combustion plant for municipal sewage sludge was used for this study. The dry flue gas treatment process produces two types of ash:

- Fly ash, which is produced by capturing the mineral fraction and heavy metals in solid form through a multicyclone and electrostatic filter. It is classified as non-hazardous waste [29] with code 190114 and labelled as FA in the paper;

- Solid waste consisting of the products of a chemical process to remove gaseous pollutants (due to the introduction of acidic sodium carbonate and activated carbon) and residual ash. Waste is caught with a bag filter. It is classified as hazardous waste [29], with code 190107 and labelled as FACH in the paper.

In the analysis of the physical and chemical properties of waste, the following tests were carried out:

- Chemical composition analysis, where waste was digested using a mixture of $\mathrm{HNO}_{3} / \mathrm{HCl}$ in a microwave oven. The obtained solution was analysed after dilution by the Inductively Coupled Plasma Spectrometry / Atomic Emission Spectroscopy (ICP-AES) and by the Inductively Coupled Plasma Mass Spectrometry (ICP-MS) with a Perkin Elmer Elan 6100 (PerkinElmer Inc., Waltham, MA, USA) apparatus;

- Leachability tests were conducted according to the EN 12457-2 standard [30]. The distilled water, with a liquid-to-solid ratio $(\mathrm{L} / \mathrm{S})$ of 10 , was used as a leaching solution. The suspension was agitated in a plastic flask for $24 \mathrm{~h}$, and then the mixture was filtered through a $0.45 \mu \mathrm{m}$ membrane filter. The resulting leachate was analysed for $\mathrm{pH}$ using potentiometric method and trace elements using the ICP-AES and ICP-MS methods. The content of chlorides was analysed using the Volhard titration method.

- The ecotoxicological properties of the tested wastes were analysed using a standard phytotoxicity test against garden cress (Lepidium sativum) and vegetation tests against Lepidium satioum and Sinapis alba. For the phytotoxicity test, an aqueous extract of the test waste was prepared, and then a series of dilutions of the aqueous extract was produced with distilled water at concentrations of: $12.5 \%, 25 \%, 50 \%$, and $100 \% .5 \mathrm{~mL}$ each of the prepared solutions was transferred (three replicates each) to Petri dishes lined with filter paper, and 10 seeds per each dish (Lepidium sativum) were introduced. Control objects were also prepared with distilled water instead of the waste aqueous extract solution (three replicates were prepared for all dilutions and controls). All test objects were left to incubate, and after $72 \mathrm{~h}$, the number of germinated seeds was determined, and the length of roots and stems was measured.

- The pot experiment consisted of growing test plants in specially prepared media, which were mixtures of universal plant growth medium $(\mathrm{pH} 5.5)$ and tested waste (content: $10 \%, 20 \%$ and $30 \%$ by volume). Reference (control) objects were also prepared, with no waste added. Ten seeds of test plants were sown into each pot; each experimental condition was produced in triplicate. Plants were grown under controlled laboratory conditions (in terms of humidity and light access). Observations of germination and early plant growth were conducted for fourteen days. One-way Analysis of variance (ANOVA) and Tukey's post-hoc tests were used to statistically evaluate the effect of the medium on plant development using the Statistica 13.1 software.

A scheme of the research framework described above is shown in Figure 1. 


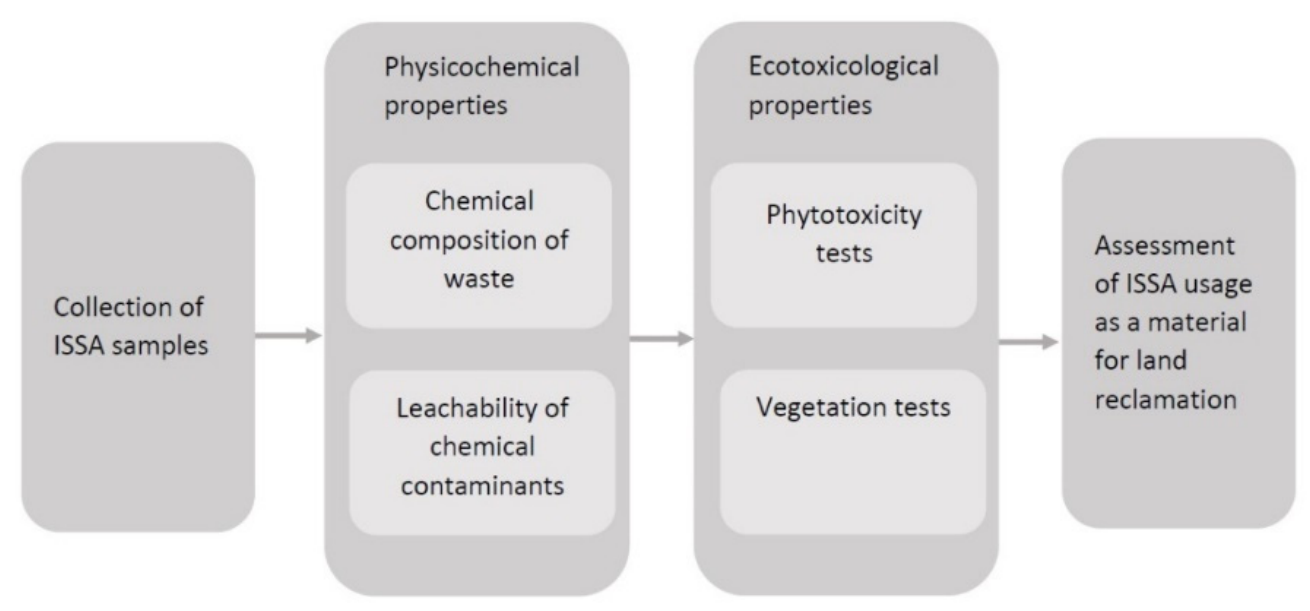

Figure 1. Research framework.

\section{Results and Discussion}

\subsection{Chemical Composition}

The results presented in Table 1 indicate significant differences in the chemical composition of the ashes studied, which is mainly due to the flue gas cleaning system consisting of two stages. In the first stage, particulates, which are the fine mineral fraction of sewage sludge and sand from the fluidised bed, are removed from flue gases using multicyclones and an electrostatic precipitator. They consist mainly of $\mathrm{SiO}_{2}, \mathrm{P}_{2} \mathrm{O}_{5}, \mathrm{CaO}, \mathrm{Al}_{2} \mathrm{O}_{3}$ and $\mathrm{MgO}$, which is confirmed by the results of studies reported by Cyr et al. and Kasina et al. [18,31]. According to the authors, ISSA mostly contains $\mathrm{P}_{2} \mathrm{O}_{5}$ contents from $10 \%$ to $26 \%$; in the studied FA ash, this value was $26.4 \%$.

Table 1. Chemical composition of the studies ashes.

\begin{tabular}{|c|c|c|c|c|c|c|c|c|c|c|c|}
\hline \multirow{2}{*}{$\begin{array}{l}\text { Symbol of } \\
\text { Waste }\end{array}$} & \multicolumn{11}{|c|}{ Chemical Composition [\% Dry Mass] } \\
\hline & $\mathrm{P}_{2} \mathrm{O}_{5}$ & $\mathrm{Mn}_{2} \mathrm{O}_{5}$ & $\mathrm{SiO}_{2}$ & $\mathrm{Al}_{2} \mathrm{O}_{3}$ & $\mathrm{Fe}_{2} \mathrm{O}_{3}$ & & $\mathrm{CaO}$ & $\mathrm{MgO}$ & $\mathrm{K}_{2} \mathrm{O}$ & $\mathrm{Na}_{2} \mathrm{O}$ & $\mathrm{SO}_{3}$ \\
\hline FA & 26.40 & 0.14 & 37.80 & 4.48 & 5.53 & & 15.93 & 3.94 & 1.65 & 0.59 & 2.07 \\
\hline $\mathrm{FACH}$ & 0.16 & 0.01 & 2.50 & 0.06 & 0.10 & & 0.27 & 0.10 & 0.05 & 34.28 & 54.52 \\
\hline \multicolumn{12}{|c|}{ Trace element content $\left[\mathrm{mg} \cdot \mathrm{kg}^{-1}\right]$} \\
\hline $\begin{array}{c}\text { Symbol of } \\
\text { waste }\end{array}$ & As & $\mathrm{Cd}$ & $\mathrm{Cr}$ & $\mathrm{Cu}$ & Co & $\mathrm{Hg}$ & $\mathrm{Ni}$ & $\mathrm{Pb}$ & $\mathrm{Ti}$ & $\mathrm{V}$ & $\mathrm{Zn}$ \\
\hline FA & 6.75 & 3.09 & 471.50 & 838.01 & 18.00 & 0.09 & 108.64 & 109.67 & 3080 & 62.99 & 3861.9 \\
\hline FACH & 0.93 & 0.01 & 6.10 & 25.24 & 0.06 & 6.29 & 0.41 & 1.39 & 1201 & 0.68 & 33.15 \\
\hline
\end{tabular}

Additionally, during the first stage of flue gas cleaning, metals, whose compounds condense on fly ash grains as a result of lowering the flue gas temperature, are removed. It applies in particular to metals such as $\mathrm{Cr}, \mathrm{Cu}, \mathrm{Ni}, \mathrm{Pb}, \mathrm{Ti}, \mathrm{Zn}, \mathrm{As}, \mathrm{Cd}$ and $\mathrm{V}$ whose contents in FA ash significantly exceeds that in FACH ash. The ash (FACH) produced in the second stage of flue gas cleaning contains mainly $\mathrm{SO}_{3}$ and $\mathrm{Na}_{2} \mathrm{O}$. This results from the chemical treatment of flue gases using acid sodium carbonate to remove acid gaseous pollutants, including $\mathrm{SO}_{\mathrm{x}}$. As the temperature in the first stage of flue gas treatment was so high that mercury remained in the gaseous phase, it is removed in the second stage by adding activated carbon. Hence the insignificant presence of $\mathrm{Hg}$ in FA ash, but significant in FACH ash. In addition, in the second stage, residual metals that remained there in the first stage were removed, hence metals such as $\mathrm{Cr}, \mathrm{Cu}, \mathrm{Ti}, \mathrm{Zn}$ are present in $\mathrm{FACH}$ ash, but in much smaller amounts than in FA ash. The metal contents were in the range reported in the literature [32]. In the case of $\mathrm{Hg}, \mathrm{Zn}$, their amounts were higher than the average. 


\subsection{Leachability of Chemical Contaminants}

Table 2 shows the results of the leachability test. Despite the presence of heavy metals in the ashes, especially in FA ash, their leachability was found to be very low. This indicates the occurrence of metals in forms insoluble or hardly soluble in water, at $\mathrm{pH} 8.45$ for FA and $\mathrm{pH} 10.66$ for FACH. These values do not exceed the permissible amounts for wastewater discharged to water or land [33]. For FA, very low amounts of chlorides $\left(3.3 \mathrm{mg} / \mathrm{dm}^{3}\right.$ with a permissible amount of $\left.1000 \mathrm{mg} / \mathrm{dm}^{3}\right)$ and sulphates $\left(826.5 \mathrm{mg} / \mathrm{dm}^{3}\right.$ with a permissible amount of $500 \mathrm{mg} / \mathrm{dm}^{3}$ ) were observed. On the other hand, the leachability of these contaminants from $\mathrm{FACH}$ is much higher, related to the process of removing acidic, gaseous pollutants from flue gases and capturing the products of purification on the bag filter. The leachability of chlorides was found to be within the permissible range, at $776 \mathrm{mg} / \mathrm{dm}^{3}$, while that of sulphates was $49,375 \mathrm{mg} / \mathrm{dm}^{3}$, which far exceeds the permissible amounts in wastewater. These values are higher than those presented for ISSA by Lynn et al. [34].

Table 2. Leachability of chemical contaminants from ash.

\begin{tabular}{|c|c|c|c|}
\hline Kind of Pollution & FA & FACH & $\begin{array}{l}\text { Acceptable Value } \\
\text { According to [33] } \\
{\left[\mathrm{mg} \cdot \mathrm{dm}^{-3}\right]}\end{array}$ \\
\hline $\mathrm{Na}$ & 66.70 & 38,608 & 800 \\
\hline $\mathrm{K}$ & 87.43 & 10.20 & 80 \\
\hline $\mathrm{Ca}$ & 237.50 & 11.43 & no requirements \\
\hline $\mathrm{Mg}$ & 86.72 & 6.66 & no requirements \\
\hline $\mathrm{Zn}$ & $<0.002 *$ & $<0.002 *$ & 2 \\
\hline $\mathrm{Cu}$ & 0.0002 & 0.0026 & 0.5 \\
\hline $\mathrm{Ni}$ & 0.0011 & 0.0003 & 0.5 \\
\hline Co & 0.00019 & 0.0001 & 1 \\
\hline $\mathrm{Pb}$ & 0.0004 & 0.0004 & 0.5 \\
\hline $\mathrm{Hg}$ & 0.0020 & 0.0001 & 0.03 \\
\hline Mn & 0.0260 & 0.0056 & no requirements \\
\hline Se & $<0.02 *$ & $<0.02 *$ & 1.0 \\
\hline $\mathrm{Cd}$ & 0.0012 & 0.00004 & 0.2 \\
\hline $\mathrm{Al}$ & 0.1070 & 3.024 & 3.0 \\
\hline $\mathrm{Cr}$ & 0.0002 & 0.0003 & 0.5 \\
\hline $\mathrm{Ti}$ & 0.0006 & 0.00001 & 1.0 \\
\hline As & 0.0136 & 0.002 & 0.1 \\
\hline Mo & 0.952 & 0.002 & 1.0 \\
\hline $\mathrm{Cl}^{-}$ & 3.3 & 776.0 & 1000 \\
\hline $\mathrm{SO}_{4}^{-2}$ & 826.50 & 49,375 & 500 \\
\hline
\end{tabular}

${ }^{*}$ value is below the limit of detection.

\subsection{Toxicity Test}

The phytotoxicity test of the tested FA against Lepidium sativum showed a favourable effect of the waste on germination of the test plants, and no inhibition of germination of plants from any of the test objects was observed in comparison to the control objects in the case of FA ashes (all seeds germinated, Figure 2). The phytotoxicity test also showed no negative effect of the aqueous extract of FA ash on the early growth of test plants. A growth-stimulating effect of the test plants relative to the control plants was found. 


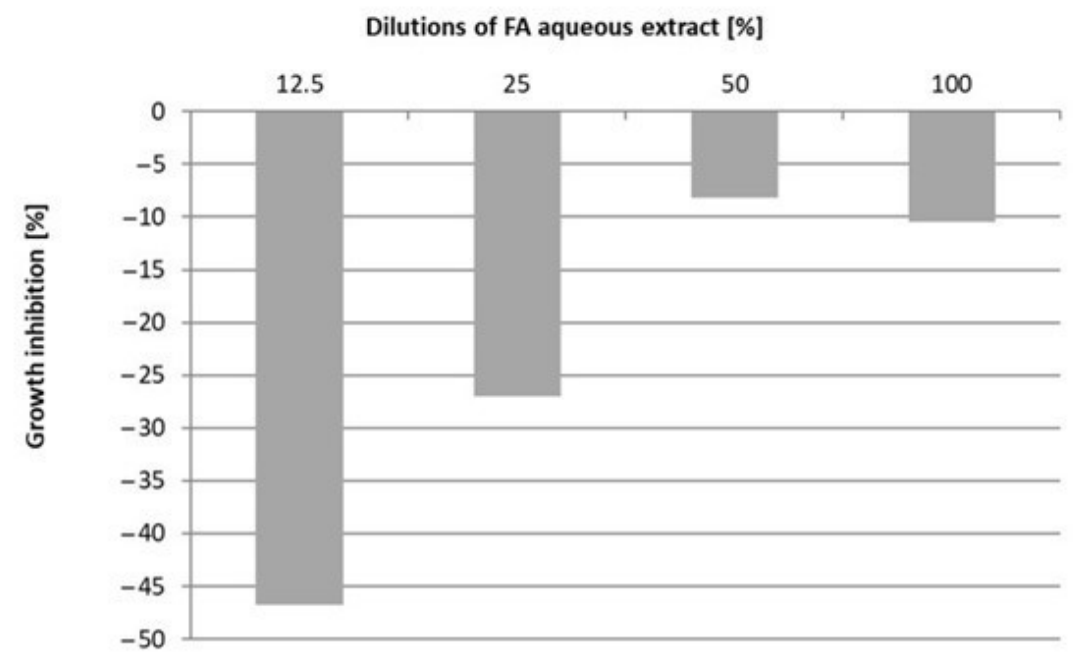

Figure 2. Growth inhibition of test plants (percentage inhibition) for different dilutions of FA aqueous extract.

Comparing the length of roots in the control and tested samples, ANOVA analysis and Tuckey tests post hoc analysis indicated that in the case of $12.5 \%$ concentration, their length is significantly longer than the length of roots in the control object (Figure 3). At the same time, there were significant differences between the length of the roots in the solution, with the concentration of $12.5 \%$ and concentrations of $50 \%$ and $100 \%$. However, no significant differences were found between the other groups (sets). In the case of the stems, the biggest difference in lengths occurred between the control sample and the sample with $100 \%$ concentration; the roots in the waste aqueous extract were found to be longer. This difference was found to be statistically significant.

Lepidium sativum

Marginal Means, Vertical bars denote $95 \%$ confidence intervals

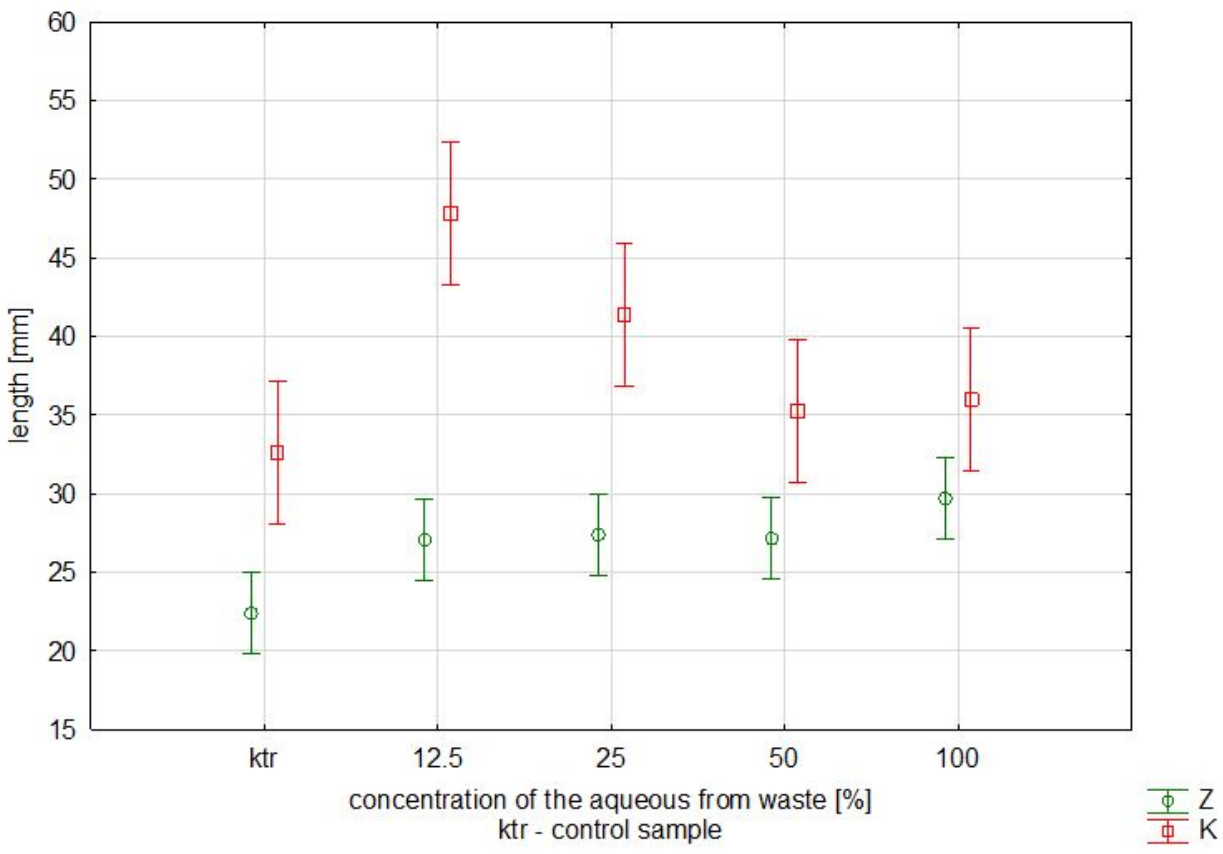

Figure 3. The growth of Lepidium sativum after $72 \mathrm{~h}$ of incubation of subsequent objects (for the studied concentrations).

In the case of FACH ash, complete inhibition of germination and growth of the test plants was found for all concentrations of the tested FACH aqueous extract. The 
phytotoxicity test result was influenced by the strongly alkaline reaction of $\mathrm{FACH}(\mathrm{pH}$ 10.66-strongly alkaline) and the high content of sulphate $\left(49,375 \mathrm{mg} \cdot \mathrm{dm}^{3}\right)$ and sodium $\left(38,608 \mathrm{mg} \cdot \mathrm{dm}^{3}\right)$ in the FACH aqueous extract.

The pot experiments carried out did not show any adverse effect of FA ash addition on the substrate on which test plants of both species (Lepidium sativum and Sinapis alba) were grown, with $10 \%$ and $20 \%$ addition of waste (Figure 4 ). A statistically significant decrease in root and shoot length of Lepidium sativum occurred only with $30 \%$ addition of waste (Figure 5).

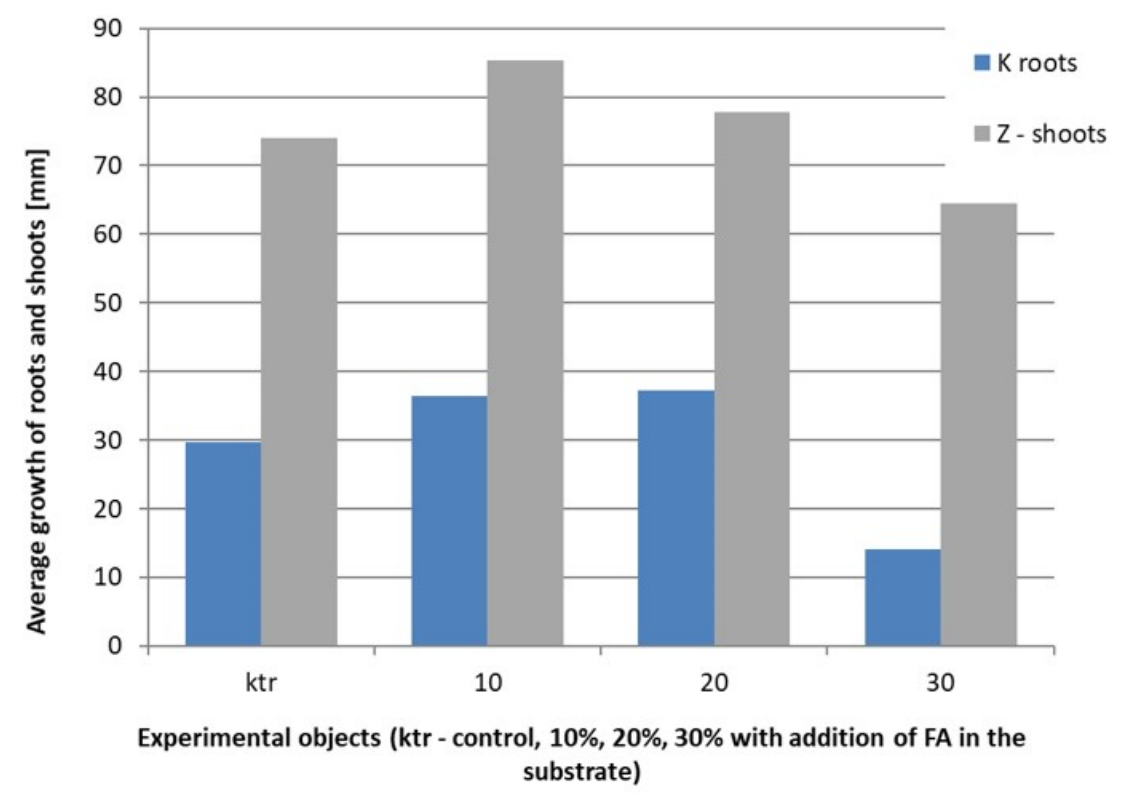

Figure 4. The growth of roots $(\mathrm{K})$ and shoots $(\mathrm{Z})$ of Lepidium sativum on the medium with different FA ash content.

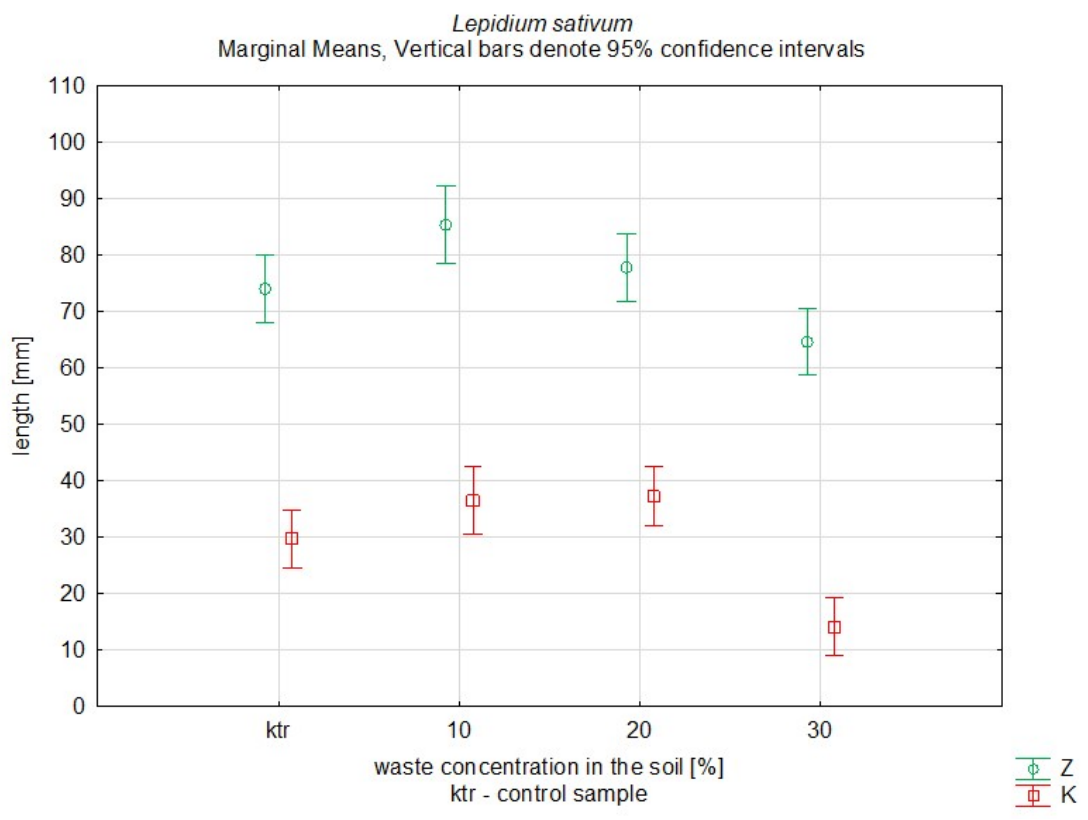

Figure 5. The growth of roots $(\mathrm{K})$ and shoots $(\mathrm{Z})$ of Lepidium sativum on the medium with various additions of waste.

The effect of stimulating the growth of roots of test plants was established for Sinapis $a l b a$ (Figures 6 and 7). Test plants grown on substrates with the addition of $10 \%$ and $20 \%$ of 
FA ash showed significantly higher root growth compared to control objects. Conversely, the addition of more than $30 \%$ FA ash to the substrate caused a significant reduction in plant growth compared to those grown on a substrate with the addition of $10 \%$ and $20 \%$ FA ash, while no statistically significant decrease in growth was observed compared to the control object (ktr).

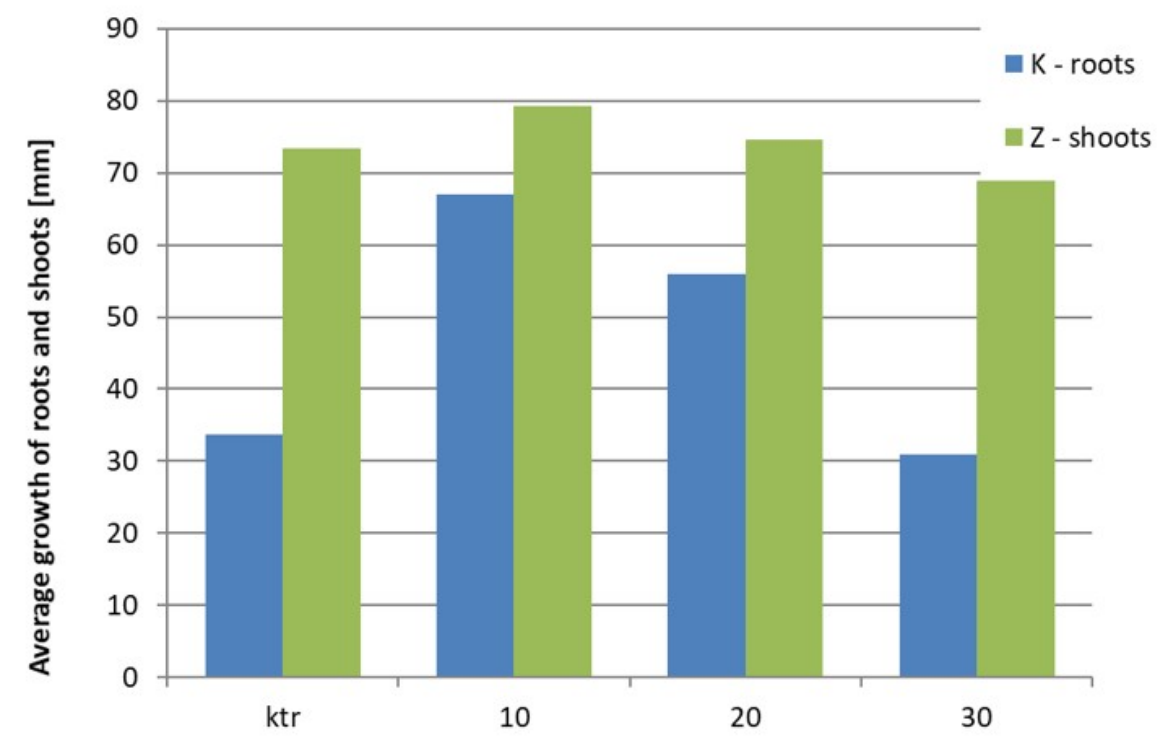

Experimental objects ( $\mathrm{ktr}$ - control, 10\%, 20\%, 30\% with addition of FA in the substrate)

Figure 6. The growth of roots (K) and shoots (Z) of Sinapis alba on the medium with different FA ash content.

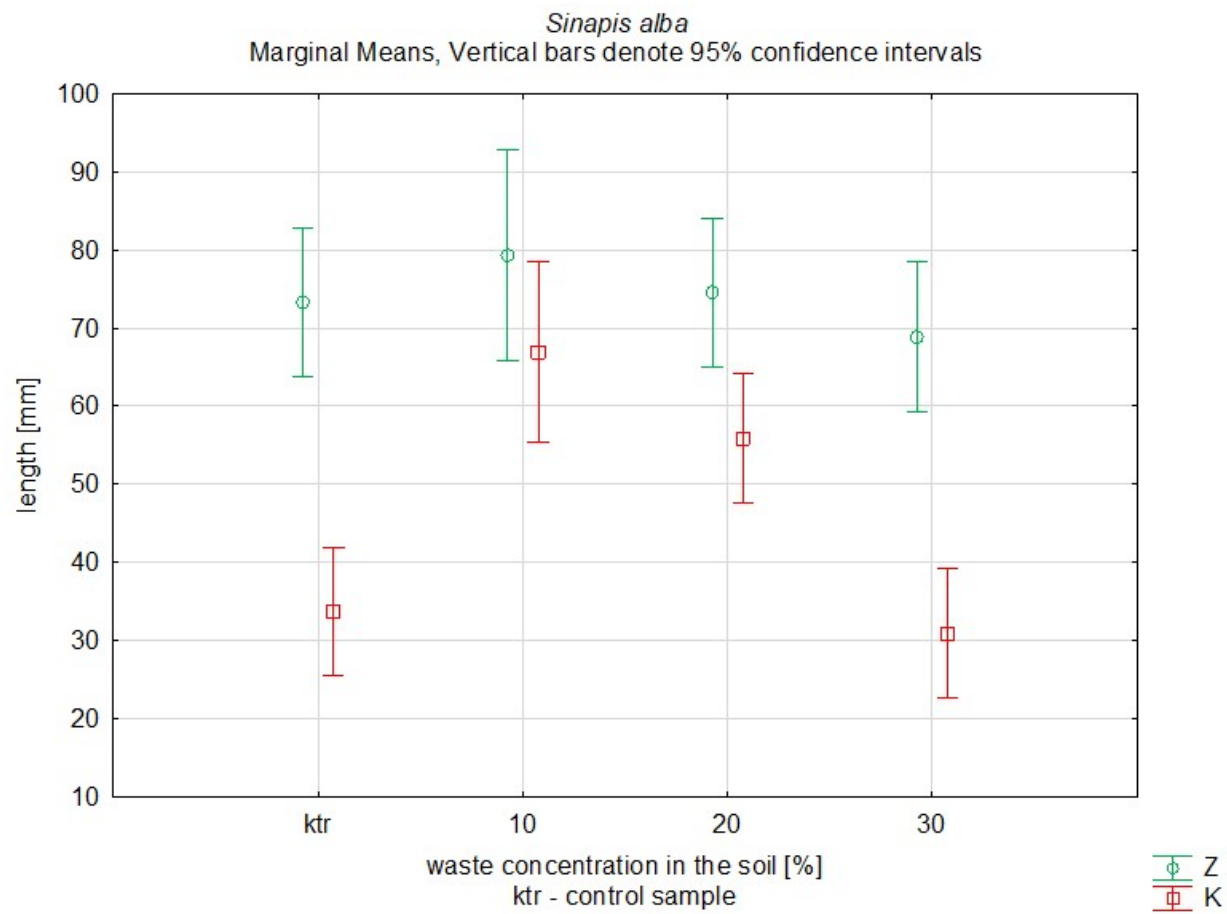

Figure 7. The growth of roots $(\mathrm{K})$ and shoots $(\mathrm{Z})$ of Sinapis alba on the medium with various additions of waste. 
Pot experiments, including the addition of FACH in the medium on which the test plants were grown, showed complete inhibition of germination and plant growth for all experimental objects (addition of $10 \%, 20 \%$ and 30\% FACH in the medium).

Ashes from the incineration of municipal sewage sludge in fluidised bed boilers may be an important source of elements necessary for plants ( $\mathrm{P}, \mathrm{K}$ and $\mathrm{Ca})$, as well as trace elements essential for living organisms, such as $\mathrm{Cr}, \mathrm{Sn}, \mathrm{Zn}, \mathrm{Co}, \mathrm{Mn}, \mathrm{Cu}, \mathrm{Mb}$ and $\mathrm{V}$. Moreover, such ashes also contain toxic metals, such as $\mathrm{Cd}, \mathrm{Hg}$, $\mathrm{As}$ and $\mathrm{Pb}$, therefore, they may pose a threat to the environment and living organisms. The bioavailability of metals depends on the chemical form of the metals and the environmental conditions, especially soil $\mathrm{pH}$, redox potential and soil type. Studies show that heavy metals present in sewage sludge are found primarily in the fractions that are more difficult to access for plants and, in the case of lead, in linkages that are inaccessible to plants [27].

The natural and fertilising use of ashes from the incineration of municipal sewage sludge may be one of the ways to reduce the storage of this type of ashes. Furthermore, ashes from the combustion of municipal sewage sludge can be a crucial source of fertilising compounds for plants, primarily due to the significant content of $P$. The results of experiments related to the possibility of using ISSA, either directly as a fertiliser or as an additive improving soil properties, indicate such a possibility for their use. However, it is essential to carefully analyse the physicochemical and ecotoxicological properties of these ashes, due to the possible higher content of heavy metals, including chlorides and sulphates, which may be hazardous to the environment $[27,28]$.

The results of this study indicate some potential to utilise ash from municipal sewage sludge (FA) incineration as a soil additive to improve the properties of reclaimed soils/land. FA phytotoxicity test against Lepidium sativum showed no phytotoxic effect of ash. The addition of ash to the growing medium at up to $20 \%$ FA in the medium also did not inhibit the growth of test plants in the pot experiment. For Lepidium sativum, no statistically significant differences in shoot and root length were observed for the above concentrations compared to the control samples. However, in the case of Sinapis alba, the addition of up to $20 \%$ ash to the medium had a stimulating effect on root growth, which was confirmed by ANOVA analysis and post-hoc tests. FA ashes contain elements necessary for proper plant growth in their composition, such as $\mathrm{P}, \mathrm{K}, \mathrm{Ca}$ and $\mathrm{Mg}$, so that they can become an important source of supplementation of these elements, especially in the case of phosphorus. Ashes contain small amounts of heavy metals (Table 1), which, due to the alkaline reaction of FA, are found primarily in insoluble forms and, therefore, are difficult for plants to access. The elevated $\mathrm{Zn}$ and $\mathrm{Cu}$ content in FA, when this ash is used as a soil additive (up to 10-20\%), should not cause an environmental hazard (Table 2), even when the phytoavailability of metals is increased due to a decrease in the $\mathrm{pH}$ of the medium.

The physicochemical properties of FACH waste and phytotoxic properties do not demonstrate the potential for natural uses of these wastes. In addition, the low nutrient content and very high chloride and sulphate content preclude the natural use of this type of waste.

\section{Conclusions}

Physicochemical and ecotoxical properities of ashes from the incineration of municipal sewage sludge greatly depend on source of their formation.

The analysis conducted in this work of selected physicochemical and phytotoxic properties of ISSA indicates the possibility of natural use of fly ash (FA). These ashes showed no phytotoxic properties; there was no inhibition of germination and early growth of the test plants (Figure 1). The addition of FA to the growing medium (in the amounts of $10 \%$ and $20 \%$ ) significantly increased the growth of the tested plants in the pot experiment. This indicates the possibility of natural use of this type of waste.

The phytotoxicity test of $\mathrm{FACH}$ ashes, containing chemical flue gas treatment products, showed complete inhibition of germination of test plants. The pot experiment conducted with the addition of FACH in the substrate inhibited plant germination as well. It excludes 
the possibility of natural use of these ashes, e.g., due to the high content of chlorides and sulphates in the waste.

The experiments conducted have shown the possibility of using some ISSA (e.g., tested FA) to improve the physicochemical properties of soils, e.g., in the reclamation of degraded land. Each use of ashes from the incineration of sewage sludge should be preceded by insightful analysis of the physicochemical and ecotoxic properties of the ash, mainly due to the threat to the environment.

The properties of ISSA can contribute to the improvement of the physicochemical properties of soils, they are also a valuable source of phosphorus and other nutrients necessary for plants. The possibility of natural use of this type of ashes is also important from the point of view of limiting their storage.

Author Contributions: Conceptualisation, W.K., M.Ś. and M.P.; Data curation, W.K., M.Ś. and M.P.; Formal analysis, W.K., M.Ś. and M.P.; Investigation, W.K., M.Ś. and M.P.; Methodology, W.K., M.Ś. and M.P.; Visualisation, W.K., M.Ś. and M.P.; Writing—original draft, W.K., M.Ś. and M.P. All authors have read and agreed to the published version of the manuscript.

Funding: This study was conducted under the scientific subsidy of the Ministry of Science and Higher Education (16.16.100.215).

Data Availability Statement: Not applicable.

Conflicts of Interest: The authors declare no conflict of interest.

\section{References}

1. Cieślik, B.; Namieśnik, J.; Konieczka, P. Review of sewage sludge management: Standards, regulations and analytical methods. J. Clean. Prod. 2015, 90, 1-15. [CrossRef]

2. Zhao, J.; Hou, T.; Zhang, Z.; Shimizu, K.; Lei, Z.; Lee, D.-J. Anaerobic co-digestion of hydrolysate from anaerobically digested sludge with raw waste activated sludge: Feasibility assessment of a new sewage sludge management strategy in the context of a local wastewater treatment plant. Bioresour. Technol. 2020, 314, 1-8. [CrossRef]

3. Cieślik, B.; Konieczka, P. A review of phosphorus recovery methods at various steps of wastewater treatment and sewage sludge management. The concept of "no solid waste generation" and analytical methods. J. Clean. Prod. 2017, 142, 1728-1740. [CrossRef]

4. Donatello, S.; Cheeseman, C.R. Recycling and recovery routes for incinerated sewage sludge ash (ISSA): A review. Waste Manag. 2013, 33, 2328-2340. [CrossRef]

5. Neuwahl, F.; Cusano, G.; Benavides, J.G.; Holbrook, S.; Roudier, S. Best Available Techniques (BAT) Reference Document for Waste Incineration; Publications Office of the European Union: Luxembourg, 2019.

6. Li, M.; Xiang, J.; Hu, S.; Sun, L.-S.; Su, S.; Li, P.-S.; Sun, X.-X. Characterization of solid residues from municipal solid waste incinerator. Fuel 2004, 83, 1397-1405. [CrossRef]

7. Vassilev, S.V.; Vassileva, C.G.; Karayigit, A.I.; Bulut, Y.; Alastuey, A.; Querol, X. Phase-mineral and chemical composition of composite samples from feed coals, bottom ashes and fly ashes at the Soma power station, Turkey. Int. J. Coal Geol. 2005, 61, 35-63. [CrossRef]

8. Borowski, G. Przetwarzanie popiołu ze spalania osadów ściekowych na materiał budowlany/Processing of ashes from sewage sludgecombustion for building material. Inżynieria Ekologiczna 2011, 25, 251-258.

9. Smol, M.; Kulczycka, J.; Henclik, A.; Gorazda, K.; Wzorek, Z. The possible use of sewage sludge ash (SSA) in the construction industry as a way towards a circular economy. J. Clean. Prod. 2015, 95, 45-54. [CrossRef]

10. Rutkowska, G.; Chalecki, M.; Żółtowski, M. Fly ash from thermal conversion of sludge as a cement substitute in concrete manufacturing. Sustainability 2021, 13, 4182. [CrossRef]

11. Rutkowska, G.; Ogrodnik, P.; Fronczyk, J.; Bilgin, A. Temperature influence on ordinary concrete modified with fly ashes from thermally conversed municipal sewage sludge strength parameters. Materials 2020, 13, 52-59.

12. Lynn, C.J.; Dhir, R.K.; Ghataora, G.S.; West, R.P. Sewage sludge ash characteristics and potential for use in concrete. Constr. Build. Mater. 2015, 98, 767-779. [CrossRef]

13. Cheeseman, C.R.; Virdi, G.S. Properties and microstructure of lightweight aggregate produced from sintered sewage sludge ash. Resour. Conserv. Recycl. 2005, 45, 18-30. [CrossRef]

14. Stempkowska, A.; Kẹpys, W.; Pietrzyk, J. Wpływ właściwości fizykochemicznych stałych pozostałości z termicznego przekształcania osadów ściekowych na możliwość ich wykorzystania w ceramice czerwonej. Gospod. Surowcami Miner. Miner. Resour. Manag. 2015, 31, 109-122.

15. Chen, L.; Lin, D.-F. Stabilization treatment of soft subgrade soil by sewage sludge ash and cement. J. Hazard. Mat. 2009, 162, 321-327. [CrossRef] [PubMed]

16. Krüger, O.; Adam, C. Recovery potential of German sewage sludge ash. Waste Manag. 2015, 45, 400-406. [CrossRef] 
17. Kepys, W.; Pomykała, R.; Pietrzyk, J. Study of the Properties of the Ash-Water Suspension of the Incinerated Sewage Sludge Ash (ISSA). Inzynieria Miner. 2014, 15, 205-212.

18. Cyr, M.; Coutand, M.; Clastres, P. Technological and environmental behavior of sewage sludge ash (SSA) in cement-based materials. Cem. Concr. Res. 2007, 37, 1278-1289. [CrossRef]

19. Smol, M.; Kulczycka, J.; Kowalski, Z. Sewage sludge ash (SSA) from large and small incineration plants as a potential source of phosphorus-Polish case study. J. Environ. Manage. 2016, 184, 617-628. [CrossRef] [PubMed]

20. Donatello, S.; Tong, D.; Cheeseman, C.R. Production of technical grade phosphoric acid from incinerator sewage sludge ash (ISSA). Waste Manag. 2010, 30, 1634-1642. [CrossRef]

21. Fang, L.; Li, J.-S.; Guo, M.Z.; Cheeseman, C.R.; Tsang, D.C.W.; Donatello, S.; Poon, C.-S. Phosphorus recovery and leaching of trace elements from incinerated sewage sludge ash (ISSA). Chemosphere 2018, 193, 278-287. [CrossRef] [PubMed]

22. Li, J.-S.; Wang, Q.; Chen, Z.; Xue, Q.; Chen, X.; Mu, Y.; Poon, C.S. Immobilization of high-Pb contaminated soil by oxalic acid activated incinerated sewage sludge ash. Environ. Pollut. 2021, 284, 117-120. [CrossRef] [PubMed]

23. Lin, W.Y.; Ng, W.C.; Wong, B.S.E.; Teo, S.L.-M.; do Sivananthan, G.; Baeg, G.H.; Ok, Y.S.; Wang, C.-H. Evaluation of sewage sludge incineration ash as a potential land reclamation material. J. Hazard. Mater. 2018, 357, 63-72. [CrossRef] [PubMed]

24. Iżewska, A.; Wołoszyk, C. Effect of fertilization with ash from municipal sewage sludge combustion on the chemical properties of light soil. Annual Set. Environ. Protect. 2014, 16, 486-497.

25. Hudziak, G.; Gorazda, K.; Wzorek, Z. Main directions in application of ash after thermal treatment of sewage sludge. Tech. Trans. Chem. 2012, 16, 41-50.

26. Krzywy, E.; Ciubak, J.; Cydzik, E.; Możdzer, E.; Kucharska, M. Utilization of municipal sewage sludge and lignite ashes for the production of fertilizer granules. Chemik 2012, 66, 1163-1168.

27. Rosik-Dulewska, C.; Nocoń, K.; Karwaczyńska, U. Wytwarzanie Granulatu z Komunalnych Osadów ściekowych i Popiołów Lotnych w celu ich Przyrodniczego (Nawozowego) Odzysku; Instytut Podstaw Inżynierii Środowiska Polskiej Akademii Nauk: Zabrze, Poland, 2016.

28. Fialova, J.; Hybska, H.; Mitterpach, J.; Samesowa, D.; Kovalicek, J.; Surowy, J.; Martauz, P. Bottom ash from municipal solid waste incineration. Basic parameters and ecotoxicological properties. Environ. Prot. Eng. 2019, 45, 113-125. [CrossRef]

29. EN 12457-2. Characterization of Waste-Leaching_Compliance Test for Leaching of Granular Waste Materials and Sludges-Part 2: One Stage Batch Test at a Liquid to Solid Ratio of 10l/kg for Materials with Particle Size below $4 \mathrm{~mm}$ (without or with Size Reduction); European Committee for Stadardization: Brussels, Belgium, 2002.

30. 2000/532/EC. Commission Decision of 3 May 2000 Replacing Decision 94/3/EC Establishing a List of Wastes Pursuant to Article 1(a) of Council Directive 75/442/EEC on Waste and Council Decision 94/904/EC Establishing a List of Hazardous Waste Pursuant to Article 1(4) of Council Directive 91/689/EEC on Hazardous Waste (Notified under Document Number C(2000) 1147); Official Journal of the European Communities. Available online: https:/ / eur-lex.europa.eu/legal-content/EN/ALL/?uri=celex\% 3A32000D0532 (accessed on 26 July 2021).

31. Kasina, M.; Kowalski, P.R.; Kajdas, B.; Michalik, M. Assessment of valuable and critical elements recovery potential in ashes from processes of solid municipal waste and sewage sludge thermal treatment. Resources 2020, 9, 131. [CrossRef]

32. Nakić, D.; Vouk, D.; Donatello, S.; Vučinić, A.A. Environmental impact of sewage sludge ash assessed through leaching. Eng. Rev. 2017, 37, 222-234.

33. Polish Legal act: Rozporządzenie Ministra Gospodarki Morskiej i Żeglugi Śródlądowej z dnia 12 lipca 2019 r. w Sprawie Substancji Szczególnie Szkodliwych dla środowiska Wodnego oraz Warunków, Jakie Należy Spełnić przy Wprowadzaniu do wód lub do Ziemi ścieków, a Także przy Odprowadzaniu wód Opadowych lub Roztopowych do wód lub do Urządzeń Wodnych. Available online: https:/ /isap.sejm.gov.pl/isap.nsf/DocDetails.xsp?id=WDU20190001311 (accessed on 25 May 2021).

34. Lynn, C.J.; Dhir, R.K.; Ghataora, G.S. Environmental impacts of sewage sludge ash in construction: Leaching assessment. Resour. Conserv. Recycl. 2018, 136, 306-314. [CrossRef] 